\title{
Handcuffs of the Beauty Myth in Maupassant's The Necklace
}

\author{
Sri Nurhidayah ${ }^{1}$ dan Apsari Fajar Prihantini ${ }^{2}$ \\ \{1 nurhidayah@stkipbim.ac.id, ${ }^{2}$ apsarifp@stkipbim.ac.id\} \\ ${ }^{1,2}$ STKIP Bina Insan Mandiri, Surabaya
}

\begin{abstract}
Women are the easiest target of a capitalist society. They are easily made insecure and uncomfortable with their physical condition. Furthermore, the patriarchal system gives more pressure to them. This situation shackles them yearning to be labeled as a 'beauty' woman. Unfortunately, not all women have the 'beauty'. Mathilde, as a representation of women live in a dramatic irony, shackled by the beauty myth. Thus, this research purposes to disclose the shackles of the beauty myth in Maupassant's The Necklace. Theoretical framework of this research is Naomi Wolf's the beauty myth. Mimetic approach is used to analyze and descriptive interpretative is the technique of analysis. The result shows that the myth definitely shackles woman. Thus, 'beauty' is the right place to maintain and strengthen the dominance of patriarchal views
\end{abstract}

Keywords: beauty myth, handcuff, Patriarchy, The Necklace, woman

\section{Introduction}

Becoming beautiful is a woman's fantasy because the socio-construction, or patriarchal perspective, distract woman status in social structure. To get this 'beautiful' appreciation, many women do everything and torture themselves. Like $18^{\text {th }}$-century British women, women willingly cut their lower ribs to form an 'ideal' waist [1]. The 'ideal' is the beautiful one. For the sake of pursuing this 'beauty image', some women give up their bodies to be the material of the creativity of the doctors on the plastic surgery table.

Apparently, beauty is not formed from an 'ideal' body shape but also the material attributes that women have. These beauty image and material attributes then make women more beautiful and captivating to men. The term beautiful composed not only from the body as beautiful face, big breasts, wide hips, and fair skin but also jewelries and fancy clothing. Accordingly, women will be judged far more beautiful when their body appearance is adorned with pendants, diamonds, and similar accessories, as well as luxurious clothes. Women who dress up with luxurious gown and jewelries get a higher value than look just beautiful in ordinary. That is how women are seen and structured.

The preceded research Julian [2], he pinpointed in giving highlight in beauty myth in Maharani's short stories. The result shows that beauty is defined by physical beauty rather intrinsic beauty. Different with Julian, this research focus on more issued in beautifying woman through not only physical appearance given but also jewelries. This research also 
suggests that woman must aware of the capitalist society as the control of beauty products. It goes without saying, woman is the most ideal targets of beauty commercial products.

Accordingly, beauty can be seen as an exchange system as well as a gold standard. Beauty is also determined by the political system. In the modern age, in eastern and western countries beauty is the last and best 'religion', which affirms the dominance of men. Beauty is an expression of power relations, where women have to compete unnaturally for resources that are adjudicated by men [3]. This is noticeably reflected in everyday life in our society. Women are the targets for vendors of beauty products, for example, cosmetics, luxury clothing, jewelry, and even offered for plastic surgery. This is very relevant to women natural desires to be considered beautiful by men and of course beauty is not enough of what we have but there are attributes that must be attached to it.

In fact, not many women have the fortune to look beautiful and adorable. However, the inability to achieve the "beauty" many women take various ways to obtain it. For example, women are courageous to sell themselves as a whore for the purpose to buy expensive and luxurious clothing, luxury jewelries far behind than to make living. Hence, women are seen as gorgeous, adorable, charming, sovereignty, glamor, and so on. Jewelries and luxurious apparel are certainly elements to support the appearance. Beautiful women who dress up in artless and humble clothes, without cosmetics, and without jewelry at all are not as beautiful and glamorous like women who dress up with the elements of beauty.

The problem arises when the desire is not in accordance with what is owned. Beauty designation and abundant jewelry ownership are the reasons why women are eager to look beautiful in men's eyes. Furthermore, women will do anything to make them look beautiful and charming in front of men. This is relevant to Mathilde in Maupassant's The Necklace [4]. The story narrates a beautiful woman, Mathilde, a wife of a clerk of low estate longing for glamorous and luxurious things that accompany her life. Living in a small and shabby look apartment, she does nothing but cries over the destiny all day long for being unfortunate and dreams escaping all the reality.

Being invited at extravagant party, she does not will to come without being a gorgeous woman with adornments. Matilda does not have fancy jewelries and fancy dresses to look charming among beautiful glamorous women. Borrowing a necklace to friend is a solution. At the party she success in making all men bow their knees and the women are jealous of her. Tragically, the necklace she lent is gone. Matilda replaces it with an expensive necklace. After a long time, it is revealed the truth about the missing necklace that it was a fake necklace and cheap 500 francs. Matilda has loss her beauty because she spends ten years of her life working to pay for a replacement necklace that is worth 36,000 francs. This story is very thoughtprovoking to be examined more deeply. Matilda is one of the women who is punished by beauty myth. Moreover, it is a reflection of our life especially for women and from this, one can understand and learn the value of it.

\section{Research Method}

The data of this research are the selected texts in the form of quotations that are suitable and classified to the problem proposed. The data were taken from Maupassant's The Necklace (1884). Thus, from the justification above, theoretical of this research is Naomi Wolf's the beauty myth. To analyze it, mimetic approach is applied. Mimetic approach can be used to comprehend literary works as the mirror of the reality [5]. From this, Maupassant's The Necklace is close to the reality. Descriptive interpretative [6] is the technique of analysis. 
Descriptive interpretative technique is applied to analyze the content and describe the problem and the data. The data are explained in details by revealing the problem proposed.

\section{Results And Discussion}

Mathilde Loisel is the main character in the story. She is a French woman living in the 19th century and a desperate housewife. She is a woman who lives in a capitalist world and has almost no control over her life. She is married to a husband and she does not care about him, and locked up in a house she hates. What she wants above all else is to be a woman that men love. The really frustrating reality is that she has all the beauty she needs. She is a beautiful, graceful woman. She just does not have the resources needed to make her more attractive and competitive with upper class women. "No; There is nothing more humiliating than to look poor among a lot of rich women" [7]. Mathilde pays more attention to wealthy and being adorable, the wealthiest woman among them and it is crucial to her. She wants to look rich so she can compete with rich women to become women who are attracted to rich men. According to her, nature's beauty is not enough to be a woman in need, but it takes wealth to transform herself into graceful woman with luxury goods.

Matilda was born with natural beauty, but her beauty is not enough to make her happy. What makes her happy is that she is a beautiful, rich, sought after woman, and she wants all women jealous of her because all men are attracted to her beauty. Matilda is longing to make all men submissive to her beauty. She is more interested in seducing men than she likes men for their personality. She hungers to be the most beautiful queen in the world, so all men desires her and all women are jealous of her. However, the wealth she possesses is not enough to make her happy. Her beauty is quite natural, but it should be adorned with glamorous and beautiful embroidered gowns. "She would so much have liked to please, to be envied, to be seductive and sought after" [7]. To support glamorous material, she and her husband unable to afford it and she borrows a necklace from her friend, Mme Forrestier.

Naomi Wolf in her book the Beauty Myth [8] assumes that beauty is given. Beauty is not an attribute attached to women since childhood. Women pay more attention to their physical appearance than men, because they adapt and adopt to patriarchal embodiment of their physical appearance. Hence, beauty is a recognition from outside world. Even other women also value each other. Furthermore, women are trapped in the myth of beauty. In fact, according to a feminist Naomi Wolf [3], the beauty myth is nothing but social control derives from patriarchal culture. This myth eventually becomes a double standard attributed and burdened women in public space. Women exist not merely because of intelligence or work skills, but because of the capital of the body: beauty.

Mathilde is a beautiful and charming woman. He is married to a man who works as a clerk in the Department of Education. "She had no dowry, no expectations, no means of being known, understood, loved, married by a man rich and distinguished; and she let them make a match for her with a little clerk in the Department of Education"[7]. Thus, Matilda' life as a woman is not in her own hands but depends on her husband. She is a woman who has a quality of life that basically depends on her family and husband. Becoming a wife of the husband and being married, she must respect her husband, but she is very frustrated and very disappointed. This is because of the myths that circulated and handcuff of patriarchy. Women are insisted to appear rich, glamorous, and respected because of the wealth they have. Matilda cannot accomplish the needs as a woman because her husband's income is not sufficient as a small clerk in the Department of Education. 
The appearance and attractiveness of a woman are not derive from or bestowed from birth. This means that the beauty of a woman is not created by itself but it is made based on the thought that embraces her to such beauty as regarded or structured. Women may think that beauty does not only come from natural beauty, but also women should dress and wrap themselves with the things that make them more attractive. This thought and perspective are not purely from the imagination of women, it is the beauty myths that make women uncomfortable with themselves. In fact, the beauty of a woman is given up since women are born [9]. Thus, all women are beautiful and women do not need to make themselves beautiful based on the beauty myth that long imprisoned women. The beauty myth makes women as if they want to look more attractive to other women that the attributes of 'beauty' itself can be accomplished when women wear fancy jewelries and glamor accessories. It is meant to be more attractive and highly desired by men. However, this beauty myth haunts women to this day unfortunately.

Women are born with natural beauty, but they are not gratified with the attractiveness they have. What does a real woman want? Men, being an attraction, become a charming woman who is able to make men bend their knees to him, have intimate male friends, have the bestlooking and richest male friends, which makes all women envious of him. A woman will be very happy when she becomes a person who is fun, jealous, who is very seductive, and is sought after by men. The beauty myth sees that quality termed 'beautiful' certainly exists, tangibly and universally. Women certainly want to have beauty, and men certainly want to have beautiful women. The pressure arising from this feeling of longing to be desired. The feeling is experienced by women, not men. This situation is transformed into something natural and necessary because it is biological, sexual, and evolutionary. Mighty men always fight for beautiful women [10]. Moreover, men are not only powerful but also have abundant wealth. Conditions like this are very pressing for women, women also want to have men who are powerful and valuable. Therefore, to captivate the heart of a man, women try hard to beautify themselves by looking in accordance with the desires and standards of beauty made by men.

Women want to be beautiful, glamorous, classy, and charming. Hence, natural beauty is not enough. Women should dress and dress themselves in fancy dress, jewelry or diamonds. Beautiful women with luxury are rich men's delusions. That thought is only in the fairy tale world, the world where women fantasize. It is reflected in "She danced with delight, with passion, intoxicated with pleasure, thinking of nothing, in the triumph of her beauty, in the glory of her success, in a sort of cloud of happiness made up of all these tributes, of all the admirations, of all these awakened desires, of this victory so complete and so sweet to a woman's heart" [7]. This statement contains the message that women's desire is to be liked by men. Being glamorous, beautiful, and well-liked by men is a female stereotype. That's what makes a woman happy. Women want to live as someone they love to signify that women are beautiful, they attract the opposite sex and make every other woman jealous of her beauty. Women are very proud of it.

The beauty gained does not correspond to the punishment that women receive in achieving the beauty. The beauty will soon fade time to time. In order to get the beauty and maintain the beauty, women have to pay a lot for it. It goes without saying, this is correlate to Matilda, borrowing the necklace from her friend, Mme Forestier and will not attend the party without the necklace. Matilda lose her head by hurting herself in numerous ways to gain the beauty defined by cultural structure. Borrowing necklace does not mean easy. Matilda must responsible to the borrowed diamond necklace. The story narrates that Matilda loses the diamond necklace after the party. She knows how expensive it is. She even believes that she 
cannot afford to buy the new one, the most similar to the expensive one. This situation shackles Matilda in a severe debt. This is the power of the handcuff of the beauty myth. She cannot control her mind to get the beauty and then, she loses the diamond necklace at once. She knows how much money to pay for it. The desire to be a beautiful and famed woman is fulfil at the moment, but she experiences prolonged suffer.

The beauty myth has worked and implanted before the birth. It goes without saying, it is in accordance with language comes before the subject. Therefore, the beauty is derived from the essence of being embodied in women by order of society[11]. The pleasure of being labelled 'beauty' is something that woman experience under the consciousness. As I can say, the subject does with pleasure without consent. What the woman does is the outmost desires beyond the mind. Matilda's desires to be beautiful woman with pendants is understood as natural will in structured society, especially in patriarchal society. On the other hand, the desires will not exist without the pressure from culture and she does it as if it is a right thing to do. Furthermore, she experiences desolate and discontent life, lack of everything indeed. Society have to take concern on women existence that they merit to be respected of what they have, not what they should be. Thus, Wolf said that "pleasure is better than frustration, and respect for female sexuality is better than disrespect for, or traumatization of, female sexuality" [12]. Hence, it can be seen from the analysis of how the beauty myth works.

The female character, Mathilde as a representation of women in all ages experiences a great sorrow in facing the reality of patriarchal society, especially in capitalist society. As a victim, she has to pay more, ten years earning money to buy the losing necklace. Because the necklace is not found, Mathilde and her husband go to Haemorhea shop and intend to buy a similar diamond necklace to replace the missing necklace she borrowed. The necklace she bought is very expensive. They cannot afford the diamond necklace. To pay for the replaced necklace, she has to work hard for ten years. This situation is stated in "Mme. Loisel seemed aged now. She had become the robust woman, hard and rough, of a poor household. Badly combed, with her skirts awry and her hands red, her voice was loud, and she washed the floor with splashing water" [7]. This situation strains her into jeopardy, because she works for ten years, she cannot take care of herself. She does not pay attention to her beauty, she loses her mind and her time working to replace the diamond necklace. Thus, she is said to be a woman who is no longer beautiful and, of course, poor. The salary she received is only used for paying the expensive necklace. She becomes an unattractive woman, looked old, and had bad days. It is very clear how the beauty myth shackles women. Moreover it is clear how the myth sees women. Women are not beautiful when she does not maintain the 'beauty' as experienced by Mathilde. Poverty and insufficiency diminish women's feminity and attractiveness, therefore they become no longer 'beautiful'.

The most startling case is the missing necklace she borrowed is lost and replaced it with a new one that is similar to an expensive price. However, Mme Forestier is surprised, and says that the missing necklace she borrowed is a fake necklace with a low price. This is where the irony happens. Here it seems the writer, Maupassant seems comparing two women who are equally beautiful with difference background. Mathilde is an unfortunate beautiful woman without treasure and on the other hands, Mme Forestier is a rich beautiful woman and treasured. In other words, women who are enchanting and treasured are the most desirable and captivating. "Then, one Sunday, as she was taking a turn in the Champs Elysées, as a recreation after the labors of the week, she felt suddenly a woman walking with a child. It was Mme. Forestier, still young, still beautiful, still seductive" [7]. Unlike Mathilde who is mislaid and unfortunate, Mme Forestier still looks gorgeous and loved. Mme Forestier has children whereas Mathilde does not have children. Therefore, it can be said that women who are 
favored by rich men are beautiful women and have wealth to make it perfect. Women who are beautiful but not wealthy are less attractive to rich men. This kind of thinking shackles women. However, Mathilde is a beautiful woman but not valuable according to traditional feminine behaviors. Women must not be seen according to patriarchal system. As Naomi states that women are demanding and suing in large part, not demonstrating many traditional feminine behaviors but being well-mannered, humanizing eloquent acquaintances, and collaborating excellently" [13]. It can be meant that women should not pay more attention on the 'body' but rather the mind. Being active and participate in social arena can be more valuable that labeled 'beauty' from patriarchal system [14].

\section{Conclusion}

From the discussion above, it can be understood that there is no nature, there is always construction. There is nothing preceding language process of signification because meaning, including beauty meaning or valuation, comes from signification process in language. If the language constructively represents patriarchal discourse, in which the category of male and female with all the attributes and roles attached to it, thus beauty is just a construction, a myth, or what so called a product of history and representation. Women become subtle (feminine) not because of the biological identity attached to them, but due to the negative imaging of them both by the discourse of science and religion which then becomes culture. The attention here is all the rules and prohibitions from the myth directly or indirectly have the purpose of pleasing men. In this case, 'beauty' is the right place to preserve and reinforce the dominance of patriarchal views. Thus, by strengthening a women's self-image, women will no longer feel disturbed because of their 'femininity', in all work opportunities and life opportunities. There's really nothing wrong with beautifying yourself, so that beauty stays sustainable. What needs to be contemplated is how women respond to deceiving seduction. This is important because women as the targeted by the owners of capital are easily made insecure and uncomfortable with their physical condition, as it is implied in the Mathilde's life.

\section{References}

[1] A. Davis, 'Racism, birth control and reproductive rights', in Feminist Postcolonial Theory a Reader, 2013.

[2] R. Julian, 'MITOS KECANTIKAN DALAM CERPEN-CERPEN DWI RATIH RAMADHANY', J. Poet., 2016.

[3] 'The beauty myth: how images of beauty are used against women', Choice Rev. Online, 1992.

[4] R. Lethbridge, G. de Maupassant, and D. Coward, 'A Day in the Country and Other Stories', Mod. Lang. Rev., 1992.

[5] A. Isenberg and M. H. Abrams, 'The Mirror and the Lamp: Romantic Theory and the Critical Tradition', J. Aesthet. Art Crit., 1954.

[6] C. Geertz, 'Thick description: Toward an interpretive theory of culture', in Interpretation of Cultures, Basic Books, 1973, pp. 3-30.

[7] G. De Maupassant, The Necklace by Guy De Maupassant. 1884.

[8] Ki. M. Long, 'Review :The Beauty Myth: How Images of Beauty are Used Against Women. By Naomi Wolf', Am. Period., 2011.

[9] Interculturaljournal, 'Women and advertising: The Beauty Myth - Part I', Intercult. J., 2008.

[10] J. Gottschall and J. Gottschall, 'The "Beauty Myth" is no Myth', in Literature, Science, and a 
New Humanities, 2008.

[11] C. Newland, 'The beauty myth', Sight and Sound. 2016.

[12] 'Vagina: a new biography', Choice Rev. Online, 2013.

[13] R. C. Hains, 'Power Feminism, Mediated: Girl Power and the Commercial Politics of Change', Women's Stud. Commun., 2009.

[14] K. Saddhono and S. Supeni. "The role of dutch colonialism in the political life of Mataram dynasty: A case study of the manuscript of Babad Tanah Jawi." Asian Soc. Sci. vol. 10 no.15 pp. $1-7,2014$ 